Revue bibliographique pour le domaine irano-aryen

\title{
Rémy Boucharlat, « Les fouilles de Babylone entre les ruines romantiques et les reconstitutions $d u$ XXIe siècle »
}

\section{Vito Messina}

\section{(2) OpenEdition Journals}

Electronic version

URL: http://journals.openedition.org/abstractairanica/45325

DOI: 10.4000/abstractairanica.45325

ISBN: 1961-960X

ISSN: 1961-960X

Publisher:

CNRS (UMR 7528 Mondes iraniens et indiens), Éditions de l'IFRI

\section{Electronic reference}

Vito Messina, «Rémy Boucharlat, « Les fouilles de Babylone entre les ruines romantiques et les reconstitutions du XXIe siècle » », Abstracta Iranica [Online], Volume 37-38-39 | 2018, document 7, Online since 30 December 2018, connection on 28 September 2020. URL : http://

journals.openedition.org/abstractairanica/45325; DOI : https://doi.org/10.4000/abstractairanica 45325

This text was automatically generated on 28 September 2020 .

Tous droits réservés 
Rémy Boucharlat, « Les fouilles de Babylone entre les ruines romantiques et les reconstitutions du XXIe siècle »

Vito Messina 


\section{REFERENCES}

Rémy Boucharlat, « Les fouilles de Babylone entre les ruines romantiques et les reconstitutions du XXIe siècle » in K. Zakharia (ed.). Babylone, Grenade : villes mythiques. Récits, réalités, représentations. Paris : Maison de l'Orient - de Boccard, 2014, p. 45-69. (Orient-Méditerranée)

1 In this article, the Author masterly overviews the history of research so far conducted at Babylon, starting from the nineteenth century, when the reputation of the sites attracted a number of western explorers and prompted major excavations at the beginning of the twentieth century. The myth of Babylon is here connected with the visual perception of its ruins and the impact of the results obtained by the German archaeologists who worked at the site, fostering attempts of reconstructing its monument and splendor. The latter face, and make more plausible, the evocative images of medieval and modern painting, but also help to correct the descriptions of ancient writers, who had only seen the ruins or even who had never come to Babylon. It is very interesting that one of the most famous features of the site, its hanging gardens, remain today untraceable, despite hypotheses of all kinds on their location and appearance: these gardens were not in Babylon but in Assyria, according to modern studies enlightened by the Author. Images of Babylon still raise our interest in modern times, also inspiring filmmakers or novelists.

\section{AUTHORS}

\section{VITO MESSINA}

Università di Torino 